\title{
Esporulação de Colletotrichum gloeosporioides em meios líquidos
}

\author{
Irene Martins ${ }^{1}$, José Ricardo Peixoto ${ }^{2}$, Zilá Ribeiro de Ávila ${ }^{1}$, Sueli Corrêa Marques de Mello ${ }^{1}$ Raquel Rocha de Pádua ${ }^{1}$
}

${ }^{1}$ Embrapa Recursos Genéticos e Biotecnologia, Av. W5 Norte (final) C.P 02372, CEP: 70770-900, Brasília/DF., e-mail: irene@cenargen.embrapa.br; ${ }^{2}$ Universidade de Brasília, Campus Universitário Darcy Ribeiro, Faculdade de Agronomia e Medicina Veterinária, C.P 04508, CEP: 70910-910. Parte da dissertação de mestrado da primeira autora.

Autor para correspondência: José Ricardo Peixoto

Data de chegada: 09/02/2006. Aceito para publicação em: 05/10/2006.

A antracnose, causada pelo fungo Colletotrichum gloeosporioides (Penzig) Saccardo, constitui-se um dos mais sérios problemas da cultura do maracujazeiro amarelo (Passiflora edulis Sims. f. flavicarpa Deg.) e outras espécies dentro da família passifloraceae, especialmente nas épocas mais quentes e úmidas do ano. O controle dessa doença envolve o emprego de variedades resistentes, agentes de controle biológico e fungicida. A seleção de variedades resistentes e de agente de controle biológico demanda grande quantidade de inóculo, fazendo-se necessário otimizar a produção de conídios para uso em bioensaios. Como C. gloeosporioides apresenta desenvolvimento limitado em meios sólidos, resultando em baixas concentrações de inóculo, esse trabalho objetivou avaliar o crescimento e a esporulação de isolados do fungo em meios líquidos.

Foram utilizados quatro isolados de C. gloeosporioides: CEN 419, CEN 421, CEN 433, obtidos de amostras de frutos e folhas de maracujazeiro, coletadas em áreas do Distrito Federal e o isolado CEN 422, cedido pela Universidade Federal Rural de Pernambuco. Os meios testados foram: V8 (Campbell $^{\circledR}$ ), BD (batata-dextrose) e BD suplementado com Extrato de Levedura a 1\% (BD+EL). A partir de culturas desenvolvidas em meio de batata-dextrose-ágar (BDA), a 25 ${ }^{\circ} \mathrm{C}$ e fotoperíodo de 12 horas, foram preparadas suspensões contendo $10^{5}$ conídios $/ \mathrm{ml}$. Cada frasco Erlenmeyer $(125 \mathrm{~mL}$ de capacidade) contendo $50 \mathrm{ml}$ dos meios indicados recebeu $5 \mathrm{~mL}$ da suspensão fúngica, sendo mantidos sob agitação $(150 \mathrm{rpm})$ a $25^{\circ} \mathrm{C}$ no escuro. Após sete dias, cada cultura foi avaliada quanto à concentração e viabilidade dos conídios e biomassa seca. A concentração de conídios foi determinada com auxílio de câmara de Newbauer e a viabilidade dos mesmos em lâminas microscópicas contendo blocos de BDA, sendo depositados em cada bloco $100 \mathrm{~mL}$ da suspensão fúngica. Contaram-se 100 conídios de cada amostra após 16 e 24 horas de incubação a $25^{\circ} \mathrm{C}$. A biomassa seca foi determinada, após filtragem em papel de filtro, e submetida à secagem em estufa por 24 horas a $70^{\circ} \mathrm{C}$. Utilizou-se o delineamento inteiramente casualizado em esquema fatorial $4 \times 3$ (4 isolados e 3 meios de cultura) com quatro repetições.

Os resultados indicaram que houve interação entre os fatores quanto ao crescimento e esporulação de C. gloeosporioides. Os isolados CEN 421 e CEN 422 superaram os demais quanto ao crescimento micelial, sendo o meio BD +EL mais adequado (Figura 1A). Os isolados CEN 419 e CEN 422, apresentaram maior capacidade de esporulação nas três composições de meios avaliadas, destacando-se, para o primeiro isolado, o meio BD e para o segundo, além deste, também o

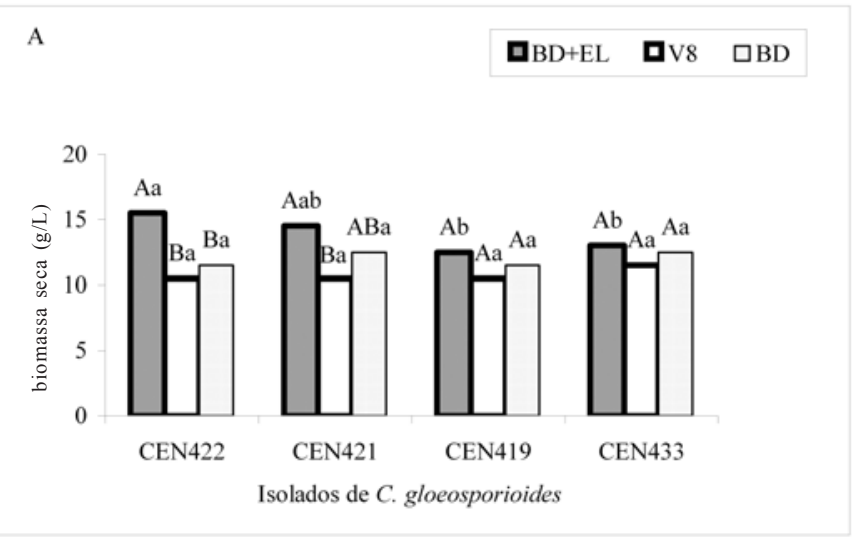

B
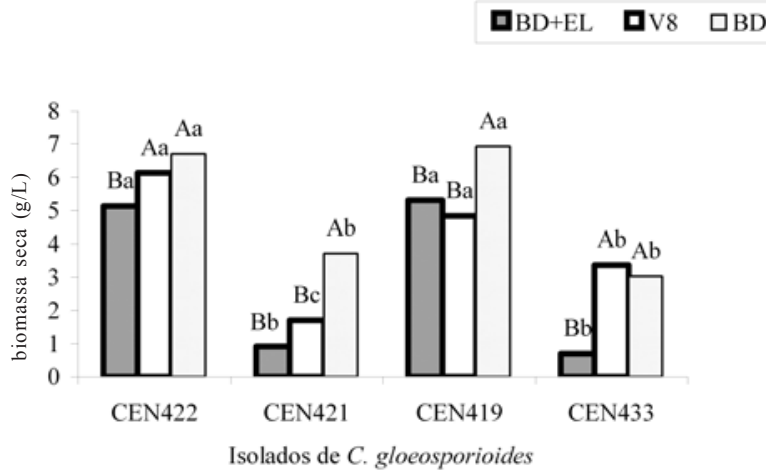

Figura 1. Produção de biomassa (A) e produção de conídios $(\mathbf{B})$ de Colletotrichum gloeosporioides em diferentes meios líquidos. Barras referidas de mesma letra não diferem estatisticamente entre si pelo teste de Tukey a $5 \%$. Letras maiúsculas comparam as médias entre os meios para cada isolado e letras minúsculas comparam as médias entre isolados para cada meio.

meio V8 (Figura 1B). Todos os isolados apresentaram viabilidade elevada após 24 horas de inoculação, independentemente do meio em que foram produzidos. Os resultados obtidos neste trabalho revelaram que é possível produzir inóculo de C. gloeosporioides em meio líquido. Este é um método relativamente rápido e que simplifica o processo de recuperação de inóculo para uso experimental em larga escala. 